\title{
Private Equity and the Flight of the Phoenix Four - the Collapse of MG Rover in the UK
}

\author{
David Bailey ${ }^{\mathrm{a}}$, lan Clark ${ }^{\mathrm{b}}$ and Alex De Ruyter ${ }^{\mathrm{c}}$ \\ ac Coventry University Business School, COVENTRY CV1 5FB, david.bailey@coventry.ac.uk \\ ${ }^{\mathbf{b}}$ Birmingham Business School, University of Birmingham, BIRMINGHAM B15 2TT, \\ i.a.clark@bham.ac.uk \\ 'Business School, University of the West of Scotland, PAISLEY PA1 2BE, alex.deruyter@uws.ac.uk
}

\begin{abstract}
This paper explores the nature of the co-called 'private equity business model' (PEBM) and assesses its shortcomings, using the illustrative example of the role of private equity in structuring the finance and subsequent collapse of MG Rover, as the automotive industry has been a significant destination for private equity financing. The paper outlines the nature of the PEBM. It then details how the PEBM extracts value, before stressing how this can affect workers in a portfolio business. We argue that the emergence of the PEBM changes the basis of competitive rules in organisations and the running of erstwhile going concerns; necessitating a need for further regulation - particularly, how to secure wider stakeholder oversight without reducing the efficiency of PEBM concerns.
\end{abstract}

\section{Keywords}

Private equity business model, automotive sector, corporate governance, economic restructuring

JEL codes

M21, N2, P12, R

\section{INTRODUCTION}

The past ten years has witnessed significant growth in company buy-outs by private equity funds; many of them on the "public2private" model, otherwise termed the private equity business model (PEBM) which increases the ratio of debt-to-equity, giving rise to the term "leverage buy-outs" (LBO). The aim of private equity acquisition, whether in the form of a buy-in to an existing private business or a public2private deal, is to unlock value for investors and the fund managers themselves. 
Public2private deals and the PEBM do this by the deployment of a business model that is principally financed through debt and financial engineering, that is, leverage secured against company assets such as freehold property and pension schemes. Acquisitions supported by the PEBM represent up to $30 \%$ of all private equity acquisitions in the UK and across the EU buy-outs of existing businesses account for $70 \%$ of all private equity investment, (PSE, 2007:45, WEF, 2008::viii; Gilligan and Wright, 2008:14; Ernst \& Young, 2008:7). Some 70\% of all funds are used simply to buy established businesses and just $5 \%$ of private equity funds are channelled into venture capital (Froud and Williams, 2007: 406).

In turn, since 2006 these deals have stimulated considerable debate and controversy over their potential impact on the health of firms and employees - particularly in the current recessionary economic climate brought about by the credit crunch (FSA, 2006; Clark, 2007; 2009b; House of Commons, 2007; GAO, 2008). Indeed, the role of private equity has been brought into sharp critical focus in the context of high-profile company collapses and subsequent closures - for example Woolworths, with the loss of some 30,000 jobs last year; and also MG Rover, the focus of this paper. Closure in turn highlights the uneven nature of the consequent socio-spatial impacts on host regions, with the closure of MGR in February 2005 having had a significant impact on the wider West Midlands economy; as the firm's turnover accounted for 0.5 to 1 percent of regional GDP, with £200 million a year alone in government revenue foregone, in addition to multiplier effects within the supply chain (Bailey and Kobayashi, 2008).

In this paper, we explore the role of the private equity business model in structuring the finance and subsequent collapse of MGR. In particular, we consider how the rise of private equity financing as a phenomenon is symptomatic of an unregulated capitalism which has served to further entrench existing patterns of inequality and uneven development across regions. In common with many sectors, the automotive industry has been a significant destination for private equity financing, especially in the supply chain, where a private equity 'gold rush' has been noted (KPMG, 2008). Yet the MG Rover case is unusual in that the 'Phoenix Four' each invested only $£ 60,000$ in a special purpose investment vehicle called 'Techtronic' to secure the MG Rover deal, with low/no cost debt funding in effect coming from BMW. In turn, the role of the Phoenix Four has come under critical scrutiny, since the publication of a Department of Business Innovation and Skills Report on the collapse of MGR (BIS, 2009). As such, it is evident that workers often end up being the last in the queue of creditors to be awarded entitlements when a company goes into liquidation, which in turn imposes real costs on them amidst a context of job loss. Indeed, it is MG Rover workers and their families who have experienced significant costs associated with the closure and as such, the human toll of the firm's collapse has been profound, as we detail below. 
As a theoretically informed yet empirically underpinned contribution to the debate, using MGR as an illustrative case, this study addresses three related research questions. First, what is the private equity business model (PEBM) and within this how are owner-investor interests positioned within this model? Second, how does the PEBM extract value from businesses? Third, how can this affect the interests of workers in a portfolio business? In so doing, the paper is structured into four substantive parts. This introduction is followed by details of the research methods utilised in this study. Part two of the paper outlines the theoretical framework of private equity, value extraction and direct ownership interests. Part three reports on the deployment of the PEBM in the so-called re-structuring of MGR after its sale by BMW in 2000 and its insolvency in 2005 - one of the less visible public2private PEBM deals in the UK. This is followed by a critically based discussion and conclusion which outlines the unregulated nature of private equity in the UK and the impact that this may have on business and workers.

This paper uses a meta-review research method which draws together material from distinct projects on which the authors' have recently been engaged and refers to a systematic evaluation of existing studies, both theoretical and empirical, supported by primary data collection from publicly available sources in the private equity sector, interviews with market experts and primary case study, interviews and documentary research. It also details the findings of an 18 month ESRC funded study into the impact of the MG Rover closure on workers, their families and communities. ${ }^{1}$ In so doing, we are able to produce a detailed case study of the application of the PEBM in the re-structuring of what was then, the sole UK based and owned volume car producer. The primary source material for much of part three of the paper comes from a forensic analysis of the department of Business report into the Affairs of Phoenix Venture Holdings and the MGR group (BIS, 2009). In summary, the paper presents a critically focussed yet empirically informed theoretically reasoned evaluation of economic and ownership re-structuring in MGR based on the application of the PEBM.

\section{THE PRIVATE EQUITY BUSINESS MODEL AND OWNER-INVESTOR INTERESTS}

\section{Private Equity and the Private Equity Business Model}

Private equity is capital raised for the specific purpose of investing directly in companies in one of two ways. The first route is indirectly, i.e. not in the direct purchase of shares in a particular firm but rather a commitment of capital to a particular private equity fund for a number of years. It is then the private equity fund which invests in (what become) portfolio firms on behalf of their investors. Secondly, and alternatively, a group of potential investors can create a special purpose investment vehicle (SIV) which in turns invests in a particular 
firm. Investments are actively managed by listed (publicly quoted) fund management companies or limited partnerships which may control numerous funds. In either form of buyout investment (direct or indirect), bespoke investment vehicles for defined projects are the favoured mechanism for the PEBM because they have no legal or taxable personality and individual partners operate collectively. Therefore, fund managers or investors (managing partners) who create the investment vehicle and investors in the vehicle (the limited partners - these two groups can be the same people) are taxed as individuals.

The term 'private equity' can be used inclusively to describe buy-outs funded from any source - or alternatively the term can be used exclusively to segment venture capital and mid-market buy-outs of private firms from those investors which specialise in the PEBM. Whilst recognising the inclusiveness of the wider approach, this paper focuses on the PEBM which is designed to re-structure established firms. Therein acquisition of listed firms, such as the MGR Group, is secured by buying a controlling percentage of shares with the aim of 're-structuring' the firm and securing a return on investment by selling the firm in three to five years. Once a partnership has control of all the shares in a portfolio company it becomes the single shareholder and the firm is no longer a publicly listed company; it is effectively 'taken private'.

Once controlled by private equity, firms respond to demands for legitimacy with key stakeholders - namely, investors and shareholders. In the contemporary period managers are either compelled or actively encouraged to adopt structures which are in the interests of these stakeholders. For example, meaningful analysis of the longer term prospects of the portfolio firm and the quality of jobs and employment relations will be contingent on first evaluating the strategic intent of private equity owners and the manner in which they deploy the PEBM post-acquisition in terms of organizational choices. Whilst the efficiency gains that deployment of the PEBM aims to secure in portfolio firms are expected to encourage restructuring towards a minimalist organization, in reality the form this takes is dependent on whether strategy is oriented towards extracting short-term value from acquired assets or renewing and developing such assets (Rodrigues and Child, 2010). Empirically, findings are mixed. Some commentators argue that this supposed 'new capitalism' exhibits a strategy of value extraction wherein efficiency is focussed on downsizing the existing scale and scope of assets and commitments to existing stakeholders including labour (Clark - forthcoming; Froud and Williams, 2007; Thornton, 2007). In contrast, others suggest that private equity ownership exhibits a strategy of value-renewal where the injection of cash can overcome the limitations of previous ownership often in the direction of resource-based approaches to managing the firm and its human resources (Bacon et al., 2010). We argue that the MG Rover case falls firmly into the first camp of value extraction given (a) the amounts taken out 
of the firm in one form or another by elite owners despite (b) the firm's losses and ultimate collapse. The latter came as little surprise given that the opportunities for value creation and renewal were extremely limited if not impossible in this case; indeed at the time of the Phoenix take-over the firm was 'virtually dead on its feet' (Bailey et al., 2008).

\section{Financialization and Investor-Owner Interests}

'Financialization' refers to structural change in capitalist economies wherein the role of finance capital comes to dominate economic and financial activity beyond financial markets in the operation of national business systems, (Clark, 2009b; Dore, 2008; Epstein, 2005: 3). Business systems subject to light touch or substantive regulation of stakeholder interests are disrupted, disembodied and re-shaped by financialization in three ways. Firstly, there is the ability of investors to secure returns unrelated to the production or supply process and the longer term running of a firm (Soros, 2008). For example, under the PEBM acquisitions are termed 'portfolio firms' thereby reifying the idea of an investment portfolio to erstwhile firms which supply goods and services, employ labour and perhaps dominate the local economy. These characteristics and the interests of stakeholders within them are of far less significance than the investor-owner interests of those who fund these acquisitions. Secondly - and directly related, financial demands increasingly dictate the behaviour of firms and change the basis of competitive rules. This development is captured theoretically in the argument that employers find it more difficult (even if they so intend) to keep their side of the bargain as a result of developments or opportunities in the financial circuit of capital. For example, at the firm level resource-based approaches to the firm are currently in vogue as a stake-holding model of leadership. However, at the business system level investor and shareholder interests may override these approaches, as firms governed by the PEBM seek to secure investment returns as quickly as possible (Thompson, 2003; Clark, 2009b).

Finally, in a global system, financialization opens up external and methodologically innovative - if alien - sources of funding, which firms may turn to in order to remain a viable, ongoing concern. Financial instruments such as off balance sheet investment vehicles are often owned or funded by private equity funds registered in banking and fiscal territories in the UK but beyond the jurisdiction of Great Britain; for example, the Isle of Man or the Channel Islands. A dialectic is present within this process as firms culturally and institutionally embedded in a particular region of a country of origin may no longer be wholly owned, managed and controlled in that territory. For example, in the UK, many premier league football teams are no longer British firms but rather are wholly owned subsidiaries of American sports franchises managed on the basis of the PEBM.

The Private Equity Sector, the PEBM and the Extraction of Value for Investors 
The private equity sector is an asset class which raises capital from investors who commit monies to a private equity fund for a period of ten years. Fund managers invest in organizations (which become) portfolio firms on behalf of investors. The sector has three segments; venture capital, mid-market buy-outs of private firms, and funds which specialise in taking listed firms private via the PEBM. The term 'private equity' can be used inclusively to describe buy-outs funded from any source or alternatively the term can be used to segment venture capital and mid-market buy-outs of private firms or orphaned corporate divisions from those partnerships which specialise in the PEBM. So whilst recognising the inclusiveness of the wider approach, this paper focuses on public2private deals or the PEBM which is designed to re-structure established firms. Here private equity partnerships acquire a controlling stake in listed firms on a publicly quoted stock market. Once a partnership has majority control of the shares in a portfolio company it becomes the dominant shareholder and shares may no longer be traded.

The PEBM is wholly distinguishable from venture capital and mid-market buy-outs as in the main these segments do not rely heavily on leverage debt to support acquisitions (Gilligan and Wright, 2008). The PEBM structures the control of businesses where investors in a fund and the partners overseeing the PEBM are wholly separate, both operationally and contractually from the portfolio firm. The justification for concentrating on the PEBM as used by larger private equity funds is threefold. One, although the term 'private equity' covers providers of venture and start-up capital and providers of 'mid-market' capital both groups stress that they provide equity capital which is not underwritten by leveraged debt. Two, notwithstanding this distinction, many academic studies of private equity aggregate different types of buy-out and the different components of the private equity sector (Thornton, 2007; Watt, 2008).

Three, in addition to this, aggregation conflates and mixes-up different types of management buy-out, for example, outside buy-ins and buy-outs some of which are and are not private equity backed on the PEBM (Bacon, et al., 2008; Wood and Wright, 2009). This conflation has led many venture capital and mid-market practitioners to seek to differentiate themselves from larger funds which concentrate on highly leveraged buy-outs on the PEBM (Rip, 2009). What results from this is twofold. First, it is important to recognize that the PEBM as defined and described herein refers to a specific portion of the private equity sector applicable to restructuring established, often, listed firms. Second, PEBM came to prominence during the period 2005-2009 when benign economic conditions (low interest rates, rising equity values and rising property values) underpinned the model. However, as economic conditions reversed highly leveraged use of the PEBM became far less viable to the extent that the model and the sector experienced 'distressed conditions' from early 2009 onwards. Here 
many portfolio firms were worth less than the loans which supported them and the sector even where it deployed the PEBM showed a preference for all cash deals often in 'fire sale' conditions. Thus, even within one small portion of the sector the dynamics of the real economy mean that it is not possible to refer to any business model as a fixed feature because practices will change and develop as the real economy changes (Harner, 2008).

The aim of private equity acquisition, whether in the form of a buy-in to an existing private business (or if a plc business is taken private either directly by investors or indirectly by a private equity fund) is to "unlock value" for investors and the fund managers themselves. The "take private" variant does this by the deployment of a business model that is principally financed through debt and financial engineering involving the divestment of company assets; for example, leverage or revenue streams secured against company assets such as freehold property and pension schemes. The PEBM can secure up to $90 \%$ of a buyout leaving the fund and its managers to put in only a small percentage themselves.

Whilst some contributors to the debate on the effects of private equity on portfolio firms provide evidence of a bias towards renewal of firms (Bacon et al., 2010), there are several sources of value extraction associated with investor-owner interests that could actually inhibit longer term renewal of a portfolio firm. First, consider downsizing and redundancy. Here, private equity firms typically view portfolio companies as a bundle of assets which can be disintegrated, downsized and separated for short-term gains, not as an integrated business which provides a service or supplies goods. For example, at the AA and Northern Rock (two firms re-structured on the PEBM), the new owners laid off a third of the existing workforce (see Clark, forthcoming). Second - and specifically related to the above, management could focus on short-term profits by unlocking valuable assets through sophisticated financial engineering to generate a "freer cash flow" via divestments of wholly owned assets or the sale and lease-back of such assets, principally property portfolios. This drives management re-structuring and unbundling prior to an "exit strategy" that aims to realize an investment after perhaps only five years.

Third (prior to the current global financial downturn), private equity owners were able to "flip" a portfolio company (or parts of it) within a very short period of time to take profits - leaving a new owner to extract value from the portion of the portfolio business they acquired. For example, many private equity owners sell-on the pension scheme of a portfolio company in the secondary private equity market, managing 'employer' contributions to it on a contractual basis which may, or may not, include a pension payment holiday. This method of value extraction has significant implications for workers if a portfolio firm becomes insolvent or if it is transferred to a loss making subsidiary of its "owners". In 2008, 23\% of the pension schemes in assessment for possible rescue by the UK Government's Pension Protection 
Fund were owned by private equity. This is a disproportionately large figure as private equity backed firms across the UK only account for around $10 \%$ of the private sector employed labour force (Close Brothers, 2008). Finally, owner-investors may consciously create an internal web of firms and owner-investor vehicle employee trusts within an initial investment with the aim of extracting value in remuneration in the most tax efficient manner. An example of how this might work is detailed in Box 1 .

\section{Box 1. The A, B, C of Re-Structuring in the PEBM}

1, Investors $\mathbf{A}$ want to buy firm $\mathbf{B}$.

2, A creates an investment vehicle called Car. Car is funded by loans which are turned into equity.

3, Car buys company B. Car becomes the shareholder of $\mathbf{B}$ taking the firm private. Car pays its investors - the new owner-managers of $\mathbf{B}$, that is $\mathbf{A}$, a salary and a bonus.

4, Car loans B funds at commercial rates, these loans are eventually re-paid to Car (a legal entity by $\mathbf{B}$, that is, to $\mathbf{A}$ the individuals (the ultimate beneficiaries) who own $\mathbf{B}$ via $\mathbf{C a r}$.

5, Car creates an off-shore investment trust called $\mathbf{D}$ for its employees and families outside GB territory and pays money into this trust as it secures revenue, its only employees are $\mathbf{A}$. Car also sells and leases back B land and property transferring some of the revenue streams from this $D$.

6, Car also set up a property vehicle $\mathbf{E}$ to manage the land sale which is owned by $\mathbf{A}$. $\mathbf{A}$ secures a commission for this work. A and Car are the same but the firm and investment vehicle are contractually, legally and hermetically sealed from one another.

7, A deposits the commission in a parallel employee trust $\mathbf{F}$ in the same territory as $\mathbf{D}$.

8, B sells some subsidiary operations at historic cost to $\mathbf{G}$. $\mathbf{G}$ is owned by Car $+\mathbf{1}$ other.

9, G sells the subsidiary at market value on the open market, the revenue accrues to Car, Car deposits the revenue stream from this in $\mathbf{D}$.

10, The individuals who make up $\mathbf{A}$ who created $\mathbf{C a r}$ and own $\mathbf{B}$ and who are the trustees of $\mathbf{D}$ and $\mathbf{E}$ and $\mathbf{F}$ and $\mathbf{G}$ are either paid a fee or a salary by all of these entities.

\section{THE PEBM AND RE-STRUCTURING AT MG ROVER, 2000-2005}

It should be stressed that the schema described in section 2 and Box 1 above is both lawful and textbook in its presentation of the PEBM and the creation of special single purpose investment vehicles and off-shore employee-owner-investor trusts. Indeed, as the critically informed chronological narrative contained in this section demonstrates, none of the actions undertaken in the re-structuring process at MGR was unlawful. The extraction of value for investors is a regular feature of the PEBM. However, what this case demonstrates is how the business model is undermined if the re-structuring process fails, that is, if investor-owners cannot re-invigorate the product via a joint venture or injection of new capital and or - critically in the MG Rover case - sell-on the business via an initial offering of shares or via the secondary private equity market. This was always going to be difficult if not impossible at MGR, and yet it did not prevent an (at the time unaccountable) value-extraction process. The value extracted in one way or another (some $£ 77$ million was taken out of MGR in one form or another) would not have been enough to save the firm in mass production guise but if used 
differently might have helped to bring a key mid-sized car to market and bought more time for a deal with Chinese partners that preserved some activities at Longbridge.

\section{BMW's Divestment of MG Rover and its Subsequent Re-Structuring: The Narrative.}

All of the material in this section is based on publically available information. Phoenix members have repeatedly stated (as we do) that they have done nothing unlawful in their attempt to re-structure MGR. The main reference source cited in this section of the paper is the department of Business Innovation and Skills Report (BIS, 2009). In 2000 MGR was a wholly-owned British subsidiary of the German car manufacturer BMW, the latter having acquired the (then profitable) Rover Group from British Aerospace in 1994 after the collapse of the latter's regional jet business and need for cash (Bailey et al., 2008).

In the spring of 2000, BMW announced publicly that it was in negotiation with a British private equity partnership - Alchemy partners - to sell MGR. At this date private equity and the PEBM were little known or understood other than that many had significant asset-stripping credentials. Fearing that MGR would be slimmed down to become a specialist non-volume producer, by Easter 2000 a Birmingham-based campaign of opposition to the Alchemy bid was underway culminating in a March for Rover in Birmingham on April $1^{\text {st }}$. At the same time four local businessmen were laying the plans for what became Phoenix Venture Holdings which was also bidding to acquire MGR. In May 2000 BMW accepted a bid from the Phoenix Consortium (A) to acquire MGR (B) through a special purpose equity-investment vehicle called Techtronic (Car). The four members of the Phoenix consortium each invested $£ 60,000$ in Techtronic shortly before it acquired MGR. In return they each received 60,000 ordinary shares in Techtronic. BMW was so keen to offload what became MGR that it sold the firm for a token $£ 10$. Moreover, in so doing BMW handed over $£ 400$ million in cash to be paid back in periodic instalments, plus $£ 75$ million in the form of loan notes in lieu of warranties and unsettled liabilities plus a stock of cars worth around another $£ 400$ million (BIS, 2009: 750).

BMW's divestment of MGR was completed on May $9^{\text {th }} 2000$ and BMW paid the first instalment of the $£ 400$ million to MGR's new owners Techtronic. In December a new entity Phoenix Venture Holdings (PVH) (Car*) acquired the 240,000 shares held in Techtronic (Car) by the four individuals $(\mathbf{A})$ often referred to as the 'Phoenix 4'. In return for these shares the four individuals acquire ' $D$ ' voting shares in PVH plus $£ 10$ million in loan notes. Other stakeholders in MGR, employees, car dealers and management team members received other non-voting shares. The four individuals (A), plus one other person, owned the controlling, that is, voting interest in PVH (Car*), this is $40 \%$ of the total share capital (FRRP, 2005: 24). At the same time as this, the MGR board agreed to pay interest on any loans that it receives from Techtronic. So, in summary and to be clear, Techtronic is not liable to pay any interest on the 
monies it was gifted/loaned by BMW but charged interest on money it lent to MGR. This move generated a revenue stream for Techtronic which, if it returned profits, would enable it to pay a dividend to PVH. Techtronic owned MGR; Techtronic was in turn owned by PVH; whose controlling owners via the ' $D$ ' shares were the four individuals known as the Phoenix 4 . These revenue streams between Techtronic and $\mathrm{PVH}$ were fully insulated from the operations of MGR which made losses in most years. Between 2001 and December 2003 MGR incurred operating losses of $£ 340$ million and draft figures for 2004 indicated an operating loss of $£ 118$ million.

In addition to re-structuring ownership of the operating business between 2001 and 2002 the MGR property portfolio was re-structured by PVH. At the end of 2001 the Longbridge site was transferred to MGR 'property holdings' (E), a subsidiary of PVH. Other transfers involved a parts business, XPart, the titles to dealer properties and those companies which owned the rights to historic names within MGR. The transfer of the Longbridge site from PVH (Car*) to E was performed at the net book value of the site in December 2001; this amounted to £36.6 million (BIS, 2009: 258). However, between April 2003 and December 2003 MGR property holdings (E) sold the site for its market value of nearly $£ 60$ million. The market value of the site in 2001 was $£ 43$ million (ibid. 262). Most of the Longbridge land was leased back to PVH not MGR via property holdings at a cost of around $£ 4$ million per year. As the BIS report makes clear the revenues derived from the sale of Longbridge were used by MGR, yet irrespective of this when MGR became insolvent in 2005 it no longer owned an asset (the sale of which was underpriced). The costs to MGR included the annual leasing costs and payments to MGR property holdings, that is, in the main PVH (Car*) which was the Phoenix 4 (A) plus one, who held a controlling interest in PVH and MGR property holdings (E). There were several historic cost transfers to subsidiary operations which were divested at market value, the most pronounced of which was the sale of XPart a parts business which became part of $\mathrm{PVH}$ for two pounds but which was subsequently sold to Caterpillar for its market value of around £31 million, again denying MGR of a valuable asset, (ibid. 761-765). ${ }^{2}$

In December 2001 a further round of financial engineering saw PVH create an off-shore employee benefit trust in Guernsey (D). This type of trust is created by an employer, in this case $\mathrm{PVH}$, in order to remunerate employees and directors in a tax efficient way. The tax efficiency arises as payments made by the employer are tax deductible for the employer but employees and directors do not incur any tax liability until the money is returned to the UK. Between May 2000 and April 2005 PHV paid a total of $£ 17$ million into the Guernsey Trust. In the main this money was distributed between the Phoenix 4 plus one other, that is, the employees and directors of $\mathrm{PVH}$. That is, $\mathbf{D}$ made payments to Car* or $\mathbf{A}$ plus one other person, (ibid. see: 598-608 for details). 
As the BIS report demonstrates, during 2003 and 2004 PVH continued to pay substantial monies into the Guernsey trust whereas some of its subsidiary operations completed the sale of former MGR assets, for example MGR property holdings' sale of the Longbridge site. Similarly, MGR sold the intellectual property rights to the Rover 75 and engine technology to $\mathrm{SAIC}^{3}$. Throughout this period MGR was trading at a loss and reported a loss of $£ 92$ million for 2003 in October 2004. By March 2005 Ernst and Young reported that PVH had insufficient cash to trade beyond the end of the month. Attempts by the DTI to broker a variety of rescue deals fail because of the failure of MGR to secure a joint alliance partnership with another auto manufacturer, and MGR went into administration in April 2005. In 2009 MGR's administrators, PWC reported that it had received up to $£ 464$ million in claims by MGR creditors. Having paid many previous claims at just $6 \%$, that is, six pence in the pound, many creditors are foregoing huge sums of money. In July 2009 the MGR administrators had just over $£ 40$ million (PWC, 2009).

\section{The Re-Structuring of MG Rover: Extracting Value via the PEBM}

The objective of private equity investors is to make money. As contributors to the academic debate demonstrate, this can be done in the main in one of two ways: either renewing the value of existing assets and later selling an investment as a re-listing or in the secondary private equity market; or alternatively investors can extract value from a business but secure it as a going concern, sell it via a re-listing or in the secondary market, or integrate the business into a larger group by way of its acquisition in a joint venture. In either case investors will secure returns and revenue streams for themselves as a result of financial engineering.

The MGR case is unusual in the sense that it was not highly leveraged. That is, the Phoenix four (latter termed the Phoenix Consortium with the addition of a $5^{\text {th }}$ person) only borrowed $£ 60,000$ each to secure the special purpose investment vehicle - Techtronic, which acquired MGR from the Phoenix 4. The debt finance effectively came from BMW via the 'dowry' which may even have been interest-rate free. However, despite this, the financial engineering entered into by the consortium is a pure example of value extraction on the PEBM. In the short-term the money loaned to MGR from BMW ensured that the firm would not fail, that is, it had sufficient capital to pay the wage bill and keep the business as a going concern. Beyond this, the MGR business plan was based on a projected revenue stream derived from the sale of one million cars in the first five years - a figure it failed to secure by some $25 \%$ in most years. In simple terms this reduced operational cash flow by about $25 \%$. The effects of this shortfall were threefold. Firstly, on the basis of cash flow (a key efficiency and performance metric for private equity operations) it reduced the profitability of the firm. Secondly and directly related to this, the reduced cash flow made MGR less attractive to a joint venture partner. This would be further reinforced if any potential joint venture partner conducted a due 
diligence exercise and realised the extent to which MGR assets (land and revenue streams from BMW) had been hollowed out by its owners, PVH. Thirdly, it reduced the funding available for new model development - critically a medium sized car which was urgently needed - further reducing the attractiveness of the firm to other players.

MGR was unusual in a second sense. Whilst PVH was not necessarily backed by substantial leverage and whilst it rolled out the PEBM, it had considerable stakeholder support in the form of local MPs and the trade unions which were recognised at the Longbridge site. Because of this and the initial pronouncements of the Phoenix 4 which centred on a stake holding approach to ownership there was little opposition to or scrutiny of the manner in which PVH secured generous financial rewards and secured and ring-fenced MGR assets at historic cost before divesting itself of them at market value. In many respects it could be argued that the trade unions were effectively 'duped' in a way they were not at other more controversial private equity buy-outs such as that at the AA. It was only after MGR's collapse that the GMB union made public its concerns about the deficits in the MGR pension fund (GMB, 2007). More significantly, the MGR case is unusual in a third sense. The absence of leverage and the 'full-on' stakeholder support buoyed the short-term business plan to run the firm out of the BMW dowry-cum-loan and revenues derived from car sales, whilst the extraction of value via asset sales and transfers was less transparent as was the value of the financial rewards for $\mathrm{PVH}$, for example the use of $£ 75$ million in BMW loan notes. Whilst $£ 10$ million of this was issued to members of $\mathrm{PVH}$ as interest bearing loan notes, the other $£ 65$ million was used as a performance bench mark for bonus payments (BIS, 2009: 754).

The key points at issue are three-fold. One, the Phoenix four and one other individual, Mr Howe, who acted as the MGR managing director were the controlling members of $\mathrm{PVH}$, as they owned all the ' $D$ ' voting shares. Two, in effect they were able to set the level of their own financial remuneration and bonus payments and payments to the Guernsey trust without challenge. Equally, they were able to set the levels of commission and payments to subsidiary entities which handled and advised on the sale of MGR assets where PVH was both controlling owner and controlling employee. Three, in terms of corporate governance and financial engineering the details of this case demonstrate how financialization has changed the nature of competitiveness in the re-structuring of a going concern. Therein trade in the revenues streams and assets of a firm appear more significant than sustaining the firm as a going concern. In terms of the argument laid out in section 2.2, financial engineering on the basis of the PEBM enabled the Phoenix consortium to extract value from MGR in the form of salaries, benefits, bonus payments, loan notes (payable to the Phoenix 4) and contributions to the employee and family trust in Guernsey of around $£ 42$ million (BIS, 2009). Alongside this, some $£ 35$ million was paid out to advisors to $\mathrm{PVH}$, bringing the total amount of money extracted to around $£ 77$ million (Bailey, 2009). ${ }^{4}$ In fact, the directors tried to extract more from the complex operations of the group. Two 'projects' called Lisa and Patto would have been 
owned by the Four, not MG Rover. For example, Patto was an attempt to reduce the indebtedness to BMW of Techtronic, which would have had the effect of increasing the value of the Four's shares. This was abandoned only when BMW realised what was going on.

\section{PRIVATE EQUITY AND THE PEBM: UNREGULATED ACTORS IN A DE-REGULATED BUSINESS SYSTEM}

In this part of the paper we draw on some of our previous work to show how PVH's use of the PEBM demonstrates how value extraction from a going concern can be achieved in the UK perfectly legally. In so doing, we do not imply that all (or even the majority) of re-structuring efforts on the PEBM seek to extract value in a manner that may, in the absence of a strategic partner, run a business into the ground. Rather, this case demonstrates the limitations of regulation as it currently stands in the UK. We do this in two ways: first by examining how UK authorities have sought to regulate private equity and the PEBM and then second, by a more detailed evaluation of the costs of the MGR collapse for workers employed there, local businesses and the wider West Midlands economy.

\section{The Regulation of Private Equity and the PEBM in the UK}

Until 2007 private equity firms operating in the UK were in the main unregulated. Stung by trade union claims of social inequality and growing perceptions across the business community that private equity benefited from preferential tax and transparency arrangements, many private equity firms began responding to media and union criticism by committing themselves to provide the names of investors but not the details of executive remuneration. In many ways these moves pre-empted the attention of the House of Commons Treasury Select Committee which examined the sector in some detail in the summer of 2007. In January 2007 the British Venture Capital and Private Equity Association (BVCA) proposed the creation of a voluntary code of conduct on reporting and transparency guidelines. In return for this the BVCA lobbied for a continuation of beneficial tax arrangements (termed the 'tax risk') which allows income to be booked as a capital gain but at a sector wide preferential rate of only $10 \%$ (since April 2008 at 18\%). ${ }^{5}$ In October 2007 the BVCA published the voluntary code of conduct hereafter termed the Walker Report (2007). This document published a series of voluntary guidelines and recommendations for the sector that included timely and effective communication with employees either directly or through a portfolio company as soon as confidentiality constraints are no longer applicable. Since 2007 the unfolding effects on workers of a free-wheeling approach to banking and finance and corporate governance evident in the global financial crisis and associated economic downturn have allegedly reset capitalism in a number of ways; not least in attitudes towards pay inequality, the emergence of 
persistent employment insecurity and concerns over corporate transparency and accountability.

However, in the UK regulation of business models that focus on investor and shareholder interests is still at an early stage. Private equity self regulation in the form of the Walker Review (2007) and reports by the associated Guide Lines Monitoring Group (GLMG) (2009) is the preferred route to voluntary self regulation. Notwithstanding this, the GLMG reported that a third of portfolio firms breached the voluntary code in 2007, many of them in the area of 'worker relations' and both the GLMG and Walker Review are anyway decidedly silent on employment relations issues, in particular on the transfer of undertakings protection in the case of acquisition by private equity. More alarmingly, the EU Commissioner for internal markets and services now appears to favour EU wide voluntary regulation on the Walker model and is rowing back from a previously avowed policy of pan-European legislative regulation, (EP, 2008; CEMA, 2008; IUF, 2009). Similarly, in the UK, the Turner Review (2009) on the global banking crisis is equally silent on private equity in the shadow banking sector and employment issues in portfolio firms, risk management systems, disclosure and 'whistle blowing' procedures for alerting management to unexpected problems and risks associated with complex financial instruments. This extends beyond employees in providers and backers of the business model to portfolio firms, particularly in the strategic use of pension funds or property portfolios by holding companies which support yet insulate bespoke investment vehicles from the branded firm they acquire.

So at the macro level of regulation in the UK economy (and in all likelihood across the EU) the private equity sector and the associated PEBM remain in the main unregulated, making a repeat of what occurred at MGR both likely and perfectly lawful. We now move from the limitations of the regulatory framework for private equity in the UK to a more grounded discussion of the effects that re-structuring MGR on the PEBM has had on the West Midlands economy and the Longbridge workforce.

\section{The Effects of the Collapse of MGR on the Workforce and Wider Regional Economy}

Given the importance of the automotive sector to the West Midlands economy, with some 53,000 jobs in the wider sector in 2005 (comprising $30 \%$ of the total sector in the UK and contributing some $6 \%$ of regional GVA; Bailey et al., 2008: 270), it was clearly evident that the subsequent closure of MGR could have had a significant adverse effect on the regional economy. Were it not for effective government intervention during the Phoenix years, under the auspices of the Rover Task Force (RTF, which consisted of representatives of central and local government, business and union organisations), helping to promote diversification away from a reliance on MGR by first and second-tier suppliers, then the adverse impact on the 
region would have been greater (Thomas et al., 2008); indeed, it is argued that the work of the first RTF between 2000 and 2005 may have saved as many as 12,000 jobs in the supply chain (ibid. 361). In the event, the closure of MGR - with the loss of some 6,000 jobs - in February 2005 still had a significant negative impact on the region, as MGR's turnover accounted for 0.5 to 1 percent of regional GDP. It has been estimated that the closure of MGR had resulted in the loss of $£ 200$ million a year alone in government revenue foregone, in addition to multiplier effects within the supply chain (Bailey and Kobayashi, 2008).

The second RTF convened upon closure to try and mitigate this situation, having secured some $£ 176$ million of government funding to further support suppliers and try and facilitate the adjustment of workers into emerging sectors, particularly through organising training provision and providing advice and assistance to those seeking work. Redundancy payments were made by the Redundancy Payments Directorate of the (then) DTI quicker than usual and the human resource function of MGR was kept on until December 2005 to assist with this. Employee pensions were effectively safeguarded, with the shortfall in the pension fund made up through the Pension Protection Fund (ibid.). In contrast to the Government's largely 'hands off' approach to industrial policy, the targeted support manifest in the Task Force approach could be said to have facilitated successful adjustment by workers. Our interviews with a representative sample of over 200 ex-MGR workers suggested that, by April 2008 (3 years after closure), some $90 \%$ of ex-MGR workers had obtained employment (75\% full-time) and further, that some $60 \%$ of ex-employees had engaged in some form of retraining or education (mainly for reasons of up-skilling or obtaining a qualification; Bailey et al., 2008b, De Ruyter et al., 2010). However, against this, it is critical to note that our survey of ex-workers found that the average earnings of ex-MGR workers had fallen by $£ 5,600$ in real terms, and this in itself concealed significant polarisation of earnings, with one third of workers having experienced a rise in earnings by April 2008 (ibid.).

If anything, the relative success of a targeted approach by government at a local level to the closure of MGR only serves to provide a sharper contrast with the systemic problems inherent in the wider UK economy and the UK Government's lax attitude to regulation of the PEBM and finance in general. Yet five years on from the closure of MGR it is evident that the situation for many of the former workers remains fragile, with the impact of the current recession being particularly evident in that workers who had found jobs had been subsequently made redundant again, or working "three-day weeks" or otherwise working on a casual or agency basis (De Ruyter et al., 2010). As one worker who had subsequently obtained a job as a tooling manager in another company commented:

"When I started with [Tool Co] they got me to employ more people. I took on 10 ex-MGR workers six months after Rover went bust - but now, of those ten, I only have three left who 
are permanent full-time. Two others are working on-and-off as casuals, and the other five have all gone.

I was going to 8 or 9 companies. Now three of them are out of business and of those that are left, most are on three-day weeks and have lost 40 to $50 \%$ of their workforce. It's carnage in the car industry at the moment' (ex-MGR worker, April 2009, cited in De Ruyter et al. 2010).

That the current financial situation of the Phoenix Four provides a marked contrast to that of the ex-workforce $(25 \%$ of whom were reporting being in financial difficulties in April 2008 before the onset of the economic downturn) has not been lost on ex-MGR workers, with workers interviewed commonly expressing anger and disgust at what they saw as the manifest enrichment of the Phoenix Four when MGR was reporting losses, the seeming abuse of the worker and community goodwill manifest in supporting PVH's takeover of MGR in 2000, and the unwillingness or inability of government to "do more" to prevent the closure (ibid).

\section{Revisiting the PEBM: the Need for More Regulation and Greater Transparency}

The developments surrounding the nature of the private equity takeover of MGR and its consequent administration by PVH only serve to reignite the debate surrounding the operation of the PEBM within the UK corporate environment, which in turn links to broader debates over the nature of regulation and systems of corporate governance. In many ways in 2010 the private equity sector remains an unregulated actor in the UK's comparatively de-regulated business system. If it is subject to any regulation at all, then 'self regulation' (in the form of the Walker guidelines for accountability and transparency (supplemented by its best practice reporting body - the guide lines monitoring group), is the order of the day. This is despite ongoing debate and concern over the situation in the sector. Started in the UK by the deliberations of the House of Commons Treasury Select Committee, the potential of the PEBM to generate huge sums for investors combined with highly preferential tax treatments was first revealed in 2007. However, the committee was inconclusive in its deliberations and whilst it did embarrass the Government into changes in the tax rate levied on private equity profits, it continued to allow profits to be booked as a capital gain not income. The use of offbalance sheet instruments (so-called special purpose investment vehicles) was left largely unregulated; so too was the thorny issue of the transfer of undertakings legislation designed to protect employee interests in the case of transfer to a new employer. Private equity buy-outs on the PEBM are not classed as a transfer of undertakings, but merely a change of majority owner.

On both issues the Treasury Select Committee argued for a pan-European evaluation of the sector. This eventually culminated in the EU Alternative Investment Fund Managers Directive. However, its name suggests the Directive is primarily concerned with the activities of hedge and private equity fund managers - not the system itself. Therein the focus of proposed 
regulation centres on the size of capital under management and the potential limits of the scale of leverage, as well as an EU-wide passport for indigenous and non EU fund managers. The issue of off-balance sheet investment vehicles appears likely to remain unregulated even though as the MG Rover case demonstrates they can be a way into a business which has a considerable portfolio of intellectual and property assets. Similarly, the Directive remains inconclusive on the issue of transfer of undertakings after making an initial suggestion that transfers of ownership by the PEBM should indeed be treated as a transfer of undertaking.

A key limitation of current approaches to regulation, whether the current position in the UK or the regulation of individuals - the most likely basis of EU wide regulation - is that both foci exclude a significant evaluation of 'systematic risk': that is the risk which is associated with the failure of the PEBM in particular circumstances, specifically those associated with special purpose investment vehicles such as Techtronic. If, for example MG Rover had been more profitable not only as a mechanism to extract value but as a more traditional going concern then fewer individuals might have been interested in the extent to which Techtronic stripped the business of value. Hence it appears to us that the key regulatory issue associated with the PEBM is one of distribution. In the MG Rover case, what some critics might refer to as 'managerial looting' is not actually so, because what occurred there and what might occur again elsewhere is actually lawful. The regulatory question centres on how to secure wider stakeholder oversight of special purpose investment vehicles without reducing the efficiency of such vehicles because they fail in a few cases.

By association the public policy stance of the last UK Labour government and in all likelihood that of the new Conservative - Liberal Democrat coalition government appears content with value extraction on the basis described herein, even though in cases such as MG Rover it actually undermines a business as a going concern. Campaigns of opposition need mobilisation at ground level such as those associated with the limitations of the PEBM in premier league football clubs. There value extraction by the Glazer family at Manchester United, or Gillette and Hicks at Liverpool, and the numerous owners of Portsmouth are now being highlighted as potentially damaging these firms as going concerns. The next level of regulatory oversight is wider stakeholder oversight for example, perhaps in securing recognised trade unions some representation in PEBM-backed investment vehicles as distinct from merely union support as in the case of MG Rover.

\section{CONCLUSION}

In this paper we have explored the nature of the private equity business model (PEBM) and assessed its shortcomings, using the highly illustrative example of the demise of MG Rover 
(MGR). We conclude that as long as policy elites support the relatively unregulated PEBM on the basis of its efficiency dynamics, PEBM failures such as MG Rover will continue to occur. Hence, not only is the question one of regulation and transparency, but also it is one of distribution and the extraction of value for the minority in the case of success or failure. This is what we mean when we suggest that the emergence of the PEBM changes the basis of competitive rules in the organization and running of erstwhile going concerns. The findings of the BIS report which laid bare the extent of value extraction and financial engineering at MG Rover are now being reviewed by the Financial Reporting Council (FRRC).

If, following the UK's 2010 general election, the new government remains committed to the previous Government's determination to "learn any lessons we can to ensure greater transparency about the impact of decisions which directors are making and the state of the companies they are running" (Lord Mandelson, in Bailey, 2009) then changes could be considered to auditing and accounting standards and guidance. Of particular interest, the BIS inspectors suggested that improvements could be made to auditing and reporting standards that would increase transparency in financial statements. The issue of 'going concern' may also need looking at again. Whilst the report also suggests that although the transfer of assets and tax losses between companies with the Rover Group was in accordance with accounting standards, readers of the financial statements would have been better informed had the "true or potential value of these assets been explained" (BIS, 2009). A shift towards making such disclosures mandatory would improve understanding of a company's financial performance. This is turn would help with the two regulatory issues associated with the PEBM. One is to do with distribution, and centres on how to secure wider stakeholder oversight of special purpose investment vehicles without reducing the efficiency of such vehicles.

The second issue may be instructive in this regard. The financial sector is made up of huge financial entities which are not easily devisable into banks of different types, hedge and private equity funds, re-insurers and credit default swap brokers. The institutional distinction between different types of banks and those institutions trading in various types of securities has all but disappeared to the extent that the labels are interchangeable, that is, all do all of the different types of trading. What is necessary to reduce the power of these institutions over the real economy is legislative restriction over their scope. Currently the interchangeable roles of branded financial institutions enable them to trade products and fund special purpose investment vehicles without oversight. Legislative reform is required to ensure that no UK bank or financial institution which contains a bank can own, invest in, or sponsor a private equity fund which is unrelated to serving its own customers for its own profit. This will restrict the trading activity of British banks in off balance sheet instruments, special purpose 
investment vehicles or securities markets such as credit default swaps which if they result in distress and flight - as in the MG Rover case - are currently secured by the taxpaper.

\section{Acknowledgments}

The authors wish to acknowledge the support of the ESRC under award number RES-000-222478, the Treasury Select Committee on private equity, and Paul Kenney, Paul Malloney and Maria Ludkin of the GMB union.

\section{Endnotes:}

1. Clark provided evidence for the Financial Services Authority review of private equity (FSA, 2006) and for the Treasury Select Committee in its examination of private equity in 2007. See also HCTSC, 2007 and Clark, 2009a; 2009b. Bailey and de Ruyter have detailed the economic and social impact of the demise of MGR as part of an ESRC-funded investigation (Armstrong et al., 2008; Bailey and Kobayashi, 2008; Thomas et al., 2008; Bailey et al., 2008b; de Ruyter et al., 2010).

2. As the BIS (2009) report makes clear, the distribution of assets and liabilities in the complex group structure meant that assets were allocated to non-MG Rover companies, while MG Rover was made to bear liabilities that should have been borne by Phoenix. Furthermore, tax losses to which MG Rover was entitled were transferred to Phoenix. This had the effect of increasing profits at Phoenix than would otherwise have been the case, and by implication the ability of the elite to extract value.

\section{Shanghai Automotive Industry Corporation.}

4. The Phoenix Four plus one other manager "chose to give themselves rewards out of all proportion to the incomes which they had previously commanded, which were also large when compared with remuneration paid in other companies and which were not obviously demanded by their qualifications and experience" (BIS, 2009).

5. In contrast to the UK position, President Obama has already pledged to charge carried interest as income not a capital gain and at the appropriate level of employment tax (Deloitte 2008: 5, 11). The White House budget office estimates that this will raise $\$ 24$ billion over 10 years. The new coalition government in the UK looks set to close this loophole by raising Capital Gains Tax to $40 \%$. 


\section{References:}

Armstrong, K., Bailey, D., De Ruyter, A., Mahdon, M. and Thomas, H. (2008) 'Auto plant closures, policy responses and labour market outcomes: a comparison of MG Rover in the UK and Mitsubishi in Australia' Policy Studies, 29 (3): 343-355.

Bacon, N., Wright, M., Demina, N., Bruining, H., Boselie, P. (2008) 'The Effects of Private Equity and Buy-Outs on HRM in the UK and the Netherlands' Human Relations 61(10) 13991433.

Bacon, N., Wright, M., Scholes, L., Meuleman, M. (2010) 'Assessing the Impact of Private Equity on Industrial Relations in Europe' Human Relations on line first published 12/2/2010

Bailey, D. (2009) Just how much money was taken out of MG Rover?' The Birmingham Post, 17/09/2009.

Bailey, D. and Kobayashi, S. (2008) 'Life After Longbridge? Crisis and Restructuring in the West Midlands Auto Cluster', in M. Farschi, O. Janne and P. McCann (eds.), Industrial Regeneration and Regional Policy Options in a Global Economy. Cheltenham: Edward Elgar.

Bailey, D., Kobayashi, S. and MacNeill, S. (2008) 'Rover and out? Globalisation, the West Midlands auto cluster, and the end of MG Rover' Policy Studies, 29 (3): 267-279.

Bailey, D., Chapain, C., Mahdon, M. and Fauth, R. (2008b) 'Life after Longbridge: Three Years on. Pathways to re-employment in a restructuring economy' The Work Foundation.

BIS, (2009) Department for Business Innovation and Skills. Report on the Affairs of Phoenix Venture Holdings Limited, MG Rover Group Limited and 33 Other Companies, Volumes 1 \& 2. The Stationary Office, www.tsoshop.co.uk

(CEMA) (2008) Committee of economic and monetary affairs (European Parliament, (2007/2238[INI]) April 2008, page 6, Draft Report. (Brussels, EU)

Clark, I. (2007) 'Private Equity and HRM in the British Business System' Human Resource Management Journal 17(3): 218-226.

Clark, I. (2009a) 'Owners Not Managers: Disconnecting Managerial Capitalism? Understanding The Private-Equity Business Model' Work, Employment and Society, 23 (4) ). 359-378.

Clark, I. (2009b) The Private Equity Business Model And Associated Strategies For HRM: Evidence And Implications? The International Journal of Human Resource Management. 20 (10): 2030-2048,

Clark, I. (2010) 'Private Equity, 'Union Recognition' and Value Extraction at the AA: The GMB As an Emergency Service'? Industrial Relations Journal. September.

Close Brothers (2008) 'Private Equity Backed Companies Less Likely to Go into The Pension Protection Fund' - Volume of Companies Going into the Pension Protection Fund Set to Treble'. www.cbfc.com September $28^{\text {th }}$

Deloitte (2008) 'Tax Policy Decision Ahead: President Elect Obama's Call for Change'. Deloitte, Washington DC.

De Ruyter, A., Bailey, D. and Mahdon, M. (2010) 'Changing Lanes or Stuck in the Slow Lane? Employment Precariousness and labour market status of MG Rover workers four years after closure' in C. Thornley, S. Jefferys and B. Appay (eds.), Globalization and Precarious Forms of Production and Employment: Challenges for Workers and Unions. Edward Elgar. Forthcoming.

Dore, R. (2008) 'Financialisation of the Global Economy' Industrial and Corporate Change 17: 1097-112. 
Epstein, G. (2005) 'Introduction' in Epstein, G. (Ed) Financialization and the World Economy Elgar, Cheltenham.

Ernst and Young (2008) 'How Do Private Equity Investors Create Value? A Global Study of 2007 Exits'. Ernst \& Young, London.

European Parliament [EP], (2008) 'Report with Recommendations to the Commission on Hedge Funds and Private Equity' (2007/2238\{INI\} CEMA, EP, Brussels, A6-0338/2008

FRRP, Financial Reporting Review Panel (2005) 'Report to the Secretary of State for Trade and Industry of a Review of the Accounts of MG Rover Group Limited and Associated Companies' 26th May. www.frc.org.uk/frrp

The Financial Services Authority (2006) 'Private Equity: A Discussion of Risk and Regulatory Engagement', Discussion Paper, 06/6, November, FSA, London.

Froud, J. and Williams, K. (2007) 'Private Equity and the Culture of Value Extraction' New Political Economy 12 (3): 405-419.

GAO (2008) 'Private Equity, Recent Growth in Leveraged Buy-Outs Exposed Risks That Warrant Continued Attention'. Report to Congressional Requesters- GAO-08-885, Washington DC.

Gilligan, J. and Wright, M. (2008) 'Private Equity DeMystified: An Exploratory Guide Corporate Finance Faculty', ICAEW, London.

GMB Union (2007) 'Private Equity's Broken Pension Promises - private equity companies' links to insolvent pension funds' A CEC Special Report. GMB, London.

Guide Lines Monitoring Group, (2009) 'Private Equity Monitoring on Transparency and Disclosure', First Report, January. walker-gmg.co.uk, London.

Harner, M. (2008) 'Corporate Governance and Public Policy Implications of Activist Distressed Debt Investing' Fordham Law Review Volume 77 pages 703-775.

House of Commons, Treasury Select Committee (2007) Tenth Report, Written and Oral Evidence, June 12th, $20^{\text {th }}$, July 3rd, Hansard Archive, www.publications.parliament.uk

IUF, (2009) 'The Commissioner, "Transparency" and Codes of Conduct: The Last Refuge of a Scoundre/? IUF Private Equity Buyout Watch March, www.iufdocuments.org

KPMG (2008) 'Private Equity in the Auto Industry'. KPMG, New York.

PSE (2007) The Socialist Group in the European Parliament. Hedge Funds and Private Equity - A Critical Analysis Draft Report, March 2007, Brussels, E.P.

PWC (2009) 'MG Rover Longbridge, MG Rover Pension Fund', PWC, Birmingham.

Rip, P. (2009) 'What Venture Capital Can Teach Corporate America' Dealbook, New York Times, May 11th.

Rodrigues, S. and Child, J. (2010) 'Private Equity, Organization and the Quality of Employment Relations' Human Relations, forthcoming.

Soros, G. (2008) 'The New Paradigm for Financial Markets - The Credit Crisis of 2008 What it Means'. New York, Public Affairs Books.

Thomas, H., Beer, A. and Bailey, D. (2008) 'A tale of two regions: comparative versus competitive approaches to economic restructuring' Policy Studies, 29 (3): 357-370.

Thompson, P. 'Disconnected Capitalism: Or Why Employers Can't Keep their Side of the Bargain' (2003) Work, Employment and Society 17:2 359-378.

Thornton, P. (2007) 'Inside the Black Box: Shedding the Light on Private Equity' The Work Foundation London, The Work Foundation. www.theworkfoundation.org 
Bailey, Clark and de Ruyter final author version for CJRES

The Turner Review (2009) 'A Regulatory Response to the Global Banking Crisis'. London, FSA.

The Walker Report (2007) 'Guidelines for Disclosure \&Transparency in Private Equity'. London, BVCA.

Watt, A.. (2008) 'The Impact of Private Equity on European Companies and Workers: Key Issues and a Review of the Evidence' Industrial Relations Journal 39:6 548-568.

Wood, G. and Wright, M. (2009) Private Equity: A Review and Synthesis. International Journal of Management Research 11(4) 361-380.

World Economic Forum (2008) 'The Global Impact of Private Equity', working papers volume 1. WEF, Switzerland. www.weforum.org 